\title{
Secondary-School-Based Interventions to Improve Muscular Strength in Adolescents: A Systematic Review
}

\author{
Carmelo García-Baños ${ }^{1}$, Jacobo Ángel Rubio-Arias ${ }^{2, *}$ (i), Luis Manuel Martínez-Aranda ${ }^{3}$ (i) and \\ Domingo Jesús Ramos-Campo ${ }^{3}$ (D) \\ 1 Secondary School Carmen de Burgos, Physical Education, 04230 Almería, Spain; carmelogb6@gmail.com \\ 2 LFE Research Group, Department of Health and Human Performance, Faculty of Physical Activity and Sport \\ Science-INEF, Polytechnic University of Madrid, 28040 Madrid, Spain \\ 3 Faculty of Sport, Catholic University of San Antonio (UCAM), 30107 Murcia, Spain; \\ lmmartinez2@ucam.edu (L.M.M.-A.); djramos@ucam.edu (D.J.R.-C.) \\ * Correspondence: ja.rubio@upm.es; Tel.: +34-910677964
}

Received: 21 July 2020; Accepted: 19 August 2020; Published: 21 August 2020

\begin{abstract}
Physical education is considered an ideal environment for improving physical fitness and muscle strength through exercise and training. This systematic review aimed to analyze studies where an intervention was implemented in Secondary School Physical Education classes to improve muscle strength. The literature search was carried out in the SPORTDiscus, PubMed, Web of Science and ScienceDirect databases. We selected randomized and nonrandomized interventions conducted in Physical Education with adolescents aged 13-18 years, where muscle strength was evaluated, comparing a control group with one or more experimental groups. From the identified works after applying the levels of screening and eligibility, eight articles were chosen for the final analysis. Data collection and risk of bias assessment were performed independently by a single reviewer. The interventions of the included studies employed varied training loads, materials, and exercises. Significant improvements were achieved in all interventions for different strength measurement tests such as the Countermovement Jump (CMJ), Standing Long Jump (SLJ) and Squat Jump (SJ) tests, medicine ball throwing test, maximum isometric strength, manual dynamometry, push-up and curl-up tests, and maximum repetition tests. Strength training can be applied safely and effectively in Secondary Education. However, methodological differences in interventions have been identified; therefore, further research is needed.
\end{abstract}

Keywords: strength training; physical education; secondary education; muscle fitness

\section{Introduction}

The latest report on physical activity in Spanish adolescents [1] estimates that only between $27 \%$ and 33\% meet the recommendations of the World Health Organization (WHO) [2] for a moderate-to-vigorous level of physical activity. Similarly, according to the ANIBES study on food and nutrition surveys [3], around $50 \%$ of children and young people spend more than two hours doing sedentary tasks during the week, reaching percentages of $85 \%$ during the weekend. In this regard, a close inverse relationship between physical activity and obesity in school children has been demonstrated [4], making this pathology one of the most relevant health problems of the 21st century, increasing exponentially from $4 \%$ in 1975 to $18 \%$ in 2016, according to WHO [5].

In parallel to these problems, it is known that an optimal level of physical condition in adolescence brings multiple benefits at the physiological, motor, and psychological levels [6]. However, one out of 
every five Spanish adolescents has a low level of physical fitness, thus a clear indication of cardiovascular risk [7].

In this context, muscle strength is one of the most relevant components of physical fitness, with enormous positive influence on health status [8] and on athletic-sports development in the medium and long term [9]. Similarly, Smith et al. [10] found a strong inverse association of strength with body fat and cardiometabolic diseases, and a positive relationship with bone health and psychological aspects such as self-perceived competition. In a psychological overview, Padilla-Moledo et al. [11] found a positive association related to academic achievement. There is also evidence of a negative relationship between strength at early ages and variables such as Body Mass Index (BMI) or insulin resistance in adulthood [12].

Despite these benefits, pediatric dynapenia is known to have gradually increased in recent years [13]. It is a condition not caused by neurological or muscular disease, characterized by low levels of strength at school age, with consequent functional limitations [14]. Therefore, it seems logical that the promotion of physical exercise in adolescents should have the improvement of strength as a central focus [15]. This promotion of exercise should have its main focus in schools and high schools since it is the place where children and adolescents spend most of their time [16]. Furthermore, as expressed by Lloyd et al. [17], between 12 and 18 months after the growth peak (around 14 years of age), thanks to the biological and maturative predisposition, a "window of opportunity" is opened, becoming a key moment to achieve a rapid increase in muscle mass and strength.

In this school framework, Physical Education is the appropriate opportunity to make motor proposals in order to improve strength, thanks to the availability of resources, the possibility of working from a long-term perspective, and the compulsory nature of the subject $[18,19]$. In fact, there is evidence that implementing intervention programs in Physical Education increases cardiorespiratory fitness [20], improves cardiometabolic risk factors [16], develops motor skills [21], and improves cognitive skills such as memory or problem-solving [22].

Lastly, due to the health problems occurring among the youngest and considering the influence of strength training on the improvement of parameters associated, as well as the relevance of Physical Education as a true health agent, the main purpose of this research was: (a) to analyze studies in which intervention programs have been developed in high schools, aiming at increasing muscle strength in adolescents, and (b) to know the characteristics of these interventions, evaluate their effectiveness, and offer evidence-based recommendations.

\section{Methods}

\subsection{Search}

This study was designed following the recommendations by the guidelines "Preferred reporting items for systematic review and meta-analysis protocols (PRISMA-P)" [23]. A detailed search of four scientific databases (SPORTDiscus, PubMed, Web of Science, and ScienceDirect) was conducted between May and July 2019. The search strategy used was: ("strength training" OR "resistance training" OR "weight training") AND ("physical education" OR "school-based" OR "school") AND (adolescent* OR teen*) AND ("intervention" OR program*) AND ("muscle strength" OR "muscular fitness").

\subsection{Eligibility Criteria and Risk of Bias Assessment}

The following specific inclusion criteria were considered: (a) articles published in English and Spanish with access to full text; (b) randomized or nonrandomized intervention comparing a control group with at least one experimental, or several experimental among them, excluding reviews, opinion articles, conference proceedings, and editorials; (c) intervention in adolescents (13-18 years) without pathologies or disabilities; (d) intervention carried out only during school hours and/or in Physical Education classes; (e) intervention carried out for a period of four weeks or more; (f) interventions where muscle strength was evaluated as the main or secondary physical capacity with a pre-post-test 
study. In addition, other variables such as cardiorespiratory endurance, static and/or dynamic postural control, or body composition (BMI, hip circumference and/or skin folds) were also measured in some cases, and practical motor intervention.

Studies were excluded if: (a) they integrated the practical intervention with some educational strategy (meetings, theoretical classes, etc.), and (b) the intervention included any type of dietary plan.

The methodological quality of the selected studies was evaluated with the Spanish translated version [24] of the Cochrane Collaboration tool for assessing risk of bias [25].

\subsection{Identification and Study Selection}

The selection process of the items is shown in the Figure 1. Of the 492 studies initially found, eight articles were included for the final qualitative analysis [26-33].

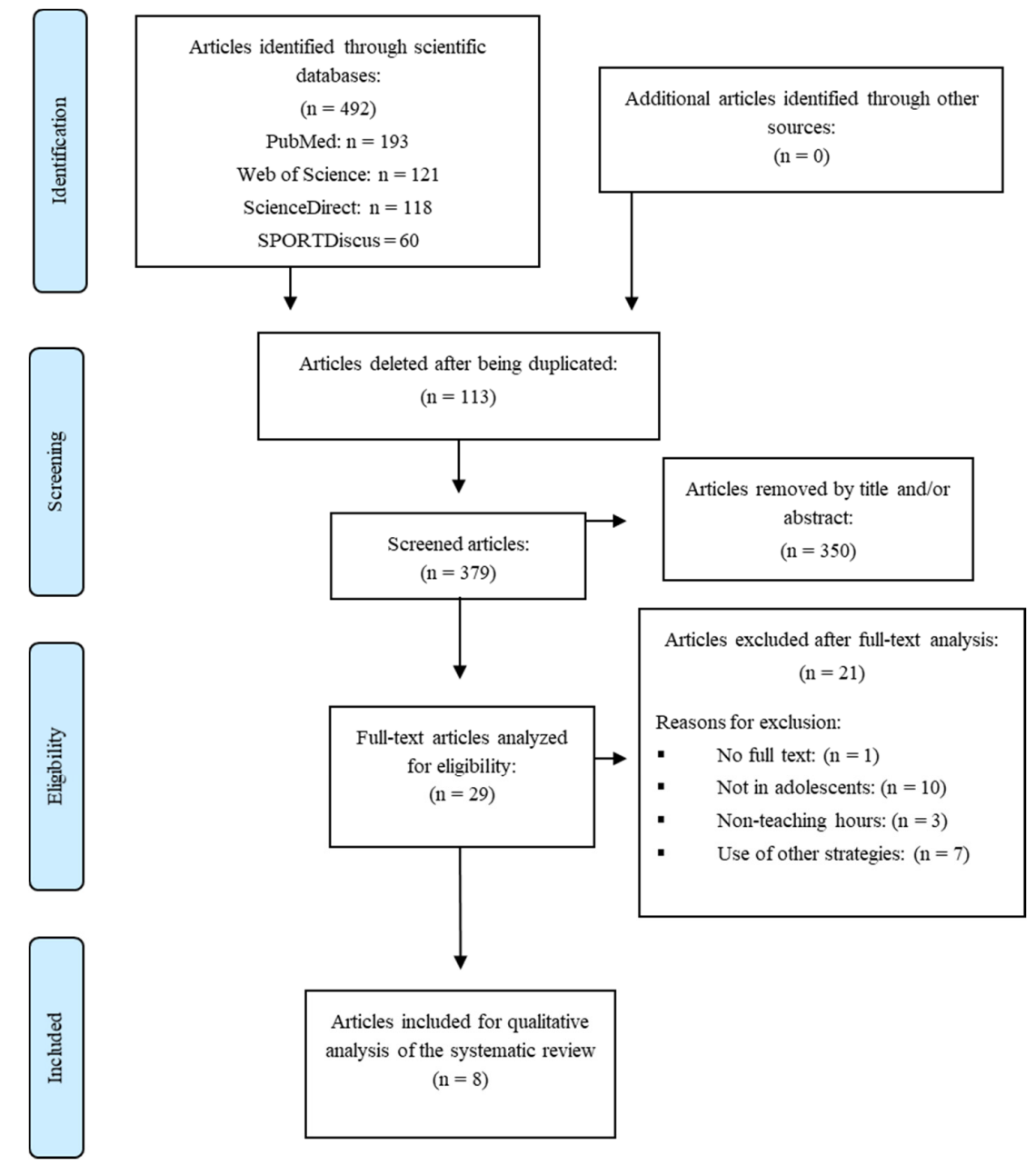

Figure 1. PRISMA flowchart of the search process. PRISMA: Preferred reporting items for systematic review and meta-analysis protocols.

\subsection{Characteristics of the Studies}

The characteristics of the selected studies are shown in Table 1. All research was published between 2009 and 2019. The sample size ranged from 24 to 222 participants; in five out of the eight studies, mixed-gender samples were analyzed [26-29,31], while in the other three studies, the participants included were exclusively male $[30,32,33]$. The mean age ( \pm standard deviation) of all these selected subjects ranged from $12.6( \pm 0.3)$ to $16.8( \pm 0.7)$. 


\subsection{Assessment of Risk of Bias}

The risk of bias assessments of all studies included in this systematic review are detailed in Figure 2. Overall, the risk of bias in the domain related to allocation concealment was high in six of the eight research studies reviewed. In addition, most studies did not provide information on whether participants and/or assessors were blinded or not.
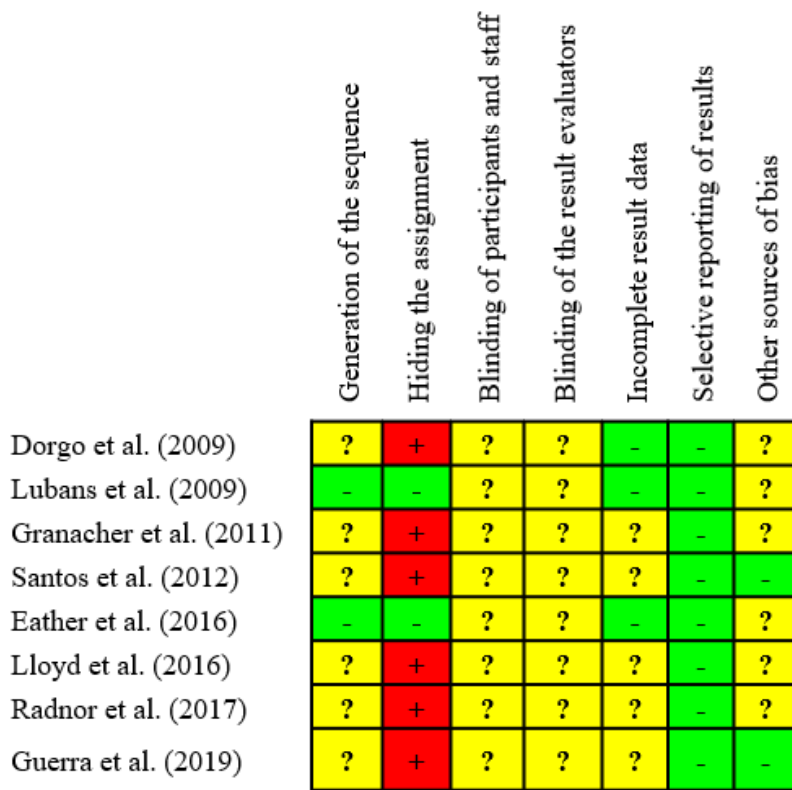

\begin{tabular}{|c|c|c|c|c|c|c|}
\hline$?$ & + & $?$ & $?$ & - & - & $?$ \\
\hline- & - & $?$ & $?$ & - & - & $?$ \\
\hline$?$ & + & $?$ & $?$ & $?$ & - & $?$ \\
\hline$?$ & + & $?$ & $?$ & $?$ & - & - \\
\hline- & - & $?$ & $?$ & - & - & $?$ \\
\hline$?$ & + & $?$ & $?$ & $?$ & - & $?$ \\
\hline$?$ & + & $?$ & $?$ & $?$ & - & $?$ \\
\hline$?$ & + & $?$ & $?$ & $?$ & - & - \\
\hline
\end{tabular}

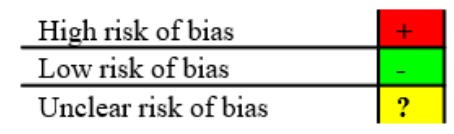

Figure 2. Summary of risk of bias of studies reviewed.

\subsection{Characteristics of Intervention Programs}

The duration of the interventions ranged from six to eight weeks, with a frequency of two sessions per week, except for the work of Dorgo et al. [26], whose intervention lasted longer, 18 weeks, with a frequency of three sessions per week. The session time was quite variable, with sessions of $45 \mathrm{~min}$ [33], $60 \mathrm{~min}[27,29,30,32]$, up to 80 [26] and $90 \mathrm{~min}$ [28], including this time the main exercises and warm-up and calm-down tasks, with a duration of 5 to $10 \mathrm{~min}$ for each of these two phases (Table 1).

In any case, all the interventions included specific strength work in one or several experimental groups, mixing upper- and lower-body training in some cases and only lower-body exercises in others. Among all the interventions, differences were observed in the number of series and repetitions, execution times, rest periods between series and/or within exercises, area worked on (upper and/or lower body), type of material (elastics bands, free weights, body weight, etc.) and the way each exercise was executed (at greater or lesser velocity). However, none of the included studies informed whether position statement or training guidelines in adolescents were followed or considered to conduct the training planning.

For all the studies, there was a control group carrying out typical activities of the ordinary Physical Education curriculum throughout the research (dynamic/group games and sports disciplines, fitness tasks, dances, adventure sports, and so on). In some cases, a second experimental group was included, whose intervention consisted of the same strength training added as the first experimental group, but incorporating training aimed at working on cardiorespiratory endurance at the end $[26,33]$. 
Table 1. Summary of the main characteristics of the studies included in this systematic review.

\begin{tabular}{|c|c|c|c|c|c|c|c|}
\hline \multirow{2}{*}{ Author/s } & \multirow{2}{*}{ Participants } & \multirow{2}{*}{ Age } & \multirow{2}{*}{ Groups } & \multicolumn{3}{|c|}{ Characteristics of the Intervention } & \multirow{2}{*}{ Measured Variables } \\
\hline & & & & Description/Volume & Duration & Frequency & \\
\hline \multirow{3}{*}{$\begin{array}{l}\text { Dorgo et al. } \\
\text { (2009) }\end{array}$} & \multirow{3}{*}{$\begin{array}{l}222 \\
\mathrm{M} / \mathrm{F} \\
\mathrm{M}=122 \\
\mathrm{~F}=100\end{array}$} & $16.0 \pm 1.2$ & $\begin{array}{l}\text { EG } \\
\text { MST }\end{array}$ & $\begin{array}{l}2 \text { laps (circuit): } \\
2 \text { to } 4 \text { sets, } 8 \text { to } 14 \text { repetitions, 3-4 exercises, 20-30" } \\
\text { rest between exercises }\end{array}$ & \multirow{3}{*}{18 weeks } & \multirow{3}{*}{$\begin{array}{c}3 \text { sessions/week } \\
- \\
80^{\prime} / \text { session }\end{array}$} & \multirow{3}{*}{$\begin{array}{l}\text { Muscle strength and endurance: } \\
\text { Abdominal incorporation (curl-up), trunk lift, push-up, } \\
\text { flexed-arm hang and modified pull-up. } \\
- \\
\text { Body composition: } \\
\text { BMI and skin folds: triceps, abdominal and cuff. } \\
- \\
\text { Cardiorespiratory resistance: } \\
\text { 1-mile running. }\end{array}$} \\
\hline & & $15.9 \pm 1.2$ & $\begin{array}{c}\text { EG } \\
\mathrm{MST}+\mathrm{CRT}\end{array}$ & $\begin{array}{c}2 \text { laps (circuit): } \\
2 \text { to } 4 \text { sets, } 8 \text { to } 14 \text { repetitions, } 3-4 \text { exercises, } 20-30 " \\
\text { rest between exercises } \\
+ \\
\text { Cardiovascular activities above } 60 \% \text { HRmax } \\
\text { (continuous running, step exercises, kickboxing } \\
\text { aerobic exercises, etc.) }\end{array}$ & & & \\
\hline & & $15.8 \pm 1.1$ & CG & $\begin{array}{c}\text { PE standardized curriculum: badminton, tennis, } \\
\text { athletics, basketball, hiking,... }\end{array}$ & & & \\
\hline \multirow[b]{3}{*}{$\begin{array}{l}\text { Lubans et al. } \\
\quad(2009)\end{array}$} & \multirow[b]{3}{*}{$\begin{array}{c}83 \\
\mathrm{M} / \mathrm{F}\end{array}$} & $\begin{array}{l}\text { Boys: } 15.3 \pm 0.8 \\
\text { Girls: } 14.9 \pm 0.6\end{array}$ & $\begin{array}{c}\text { EG } \\
\text { ETST }\end{array}$ & $\begin{array}{c}2 \text { sets, } 8 \text { to } 12 \text { repetitions, } 10 \text { exercises, } 60-90^{\prime \prime} \text { rest } \\
\text { between sets. }\end{array}$ & \multirow[b]{3}{*}{$\begin{array}{c}8 \\
\text { weeks }\end{array}$} & \multirow{3}{*}{$\begin{array}{c}2 \text { sessions } / \text { week } \\
- \\
60^{\prime} / \text { session }\end{array}$} & \multirow{3}{*}{$\begin{array}{l}\text { Muscle strength: 1RM test } \\
\text { Hip circumference. }\end{array}$} \\
\hline & & $\begin{array}{l}\text { Boys: } 15.0 \pm 0.6 \\
\text { Girls: } 15.1 \pm 0.7\end{array}$ & $\begin{array}{c}\text { EG } \\
\text { FWST }\end{array}$ & $\begin{array}{c}2 \text { sets, } 8 \text { to } 12 \text { repetitions, } 10 \text { exercises, } 60-90^{\prime \prime} \text { rest } \\
\text { between sets. }\end{array}$ & & & \\
\hline & & $\begin{array}{l}\text { Boys: } 14.8 \pm 0.4 \\
\text { Girls: } 14.5 \pm 0.6\end{array}$ & CG & PE standardized curriculum. & & & \\
\hline \multirow[t]{2}{*}{$\begin{array}{l}\text { Granacher et al. } \\
\quad \text { (2011) }\end{array}$} & \multirow{2}{*}{$\begin{array}{l}28 \\
\mathrm{M} / \mathrm{F} \\
- \\
\mathrm{M}=13 \\
\mathrm{~F}=15\end{array}$} & $16.7 \pm 0.6$ & $\begin{array}{l}\text { EG } \\
\text { BST }\end{array}$ & $\begin{array}{c}4 \text { sets, } 10 \text { repetitions, } 5 \text { exercises, } 2-3^{\prime} \text { rest } \\
\text { between sets }\end{array}$ & \multirow[t]{2}{*}{$\begin{array}{c}8 \\
\text { weeks }\end{array}$} & \multirow{2}{*}{$\begin{array}{c}2 \text { sessions/week } \\
- \\
90^{\prime} / \text { session } \\
+ \\
7 \text { weeks of detraining }\end{array}$} & $\begin{array}{l}\text { Body composition: BMI, \% body fat and \% fat-free mass. } \\
\text { Static and dynamic postural control } \\
- \\
\text { Height of the vertical countermovement Jump (CMJV) }\end{array}$ \\
\hline & & $16.8 \pm 0.7$ & CG & $\begin{array}{l}\text { PE standardized curriculum: gymnastic skills, } \\
\text { swimming, etc. }\end{array}$ & & & $\begin{array}{c}\text { Maximum isometric force (MIF) } \\
\text { Rate of Force Development (RFD) }\end{array}$ \\
\hline \multirow{3}{*}{$\begin{array}{l}\text { Santos et al. } \\
\quad(2012)\end{array}$} & \multirow{3}{*}{$\begin{array}{l}42 \\
\mathrm{M}\end{array}$} & \multirow{3}{*}{$13.3 \pm 1.04$} & $\begin{array}{l}\text { EG } \\
\text { PT }\end{array}$ & $\begin{array}{l}\text { Medicine ball throws ( } 1 \text { and } 3 \mathrm{~kg}) \\
\text { countermovement jumps on a box, plyometric } \\
\text { jumps between hurdles and sprints of } 30 \text { to } 40 \mathrm{~m}\end{array}$ & \multirow{3}{*}{$\begin{array}{c}8 \\
\text { weeks }\end{array}$} & \multirow{3}{*}{$\begin{array}{c}2 \text { sessions/week } \\
- \\
45^{\prime} \text { session } 1 \\
90^{\prime} \text { session } 2 \\
+ \\
12 \text { weeks of } \\
\text { detraining }\end{array}$} & $\begin{array}{c}\text { Anthropometric assessment: } \\
\text { Body weight, BMI and \% body fat. } \\
-\end{array}$ \\
\hline & & & $\begin{array}{c}\text { EG } \\
\text { PT + CRT }\end{array}$ & $\begin{array}{c}\text { Medicine ball throws }(1 \text { and } 3 \mathrm{~kg}) \\
\text { countermovement jumps on a box, plyometric } \\
\text { jumps between hurdles and sprints of } 30 \text { to } 40 \mathrm{~m} \\
+ \\
+ \\
20-\mathrm{m} \text { round-trip test. }\end{array}$ & & & $\begin{array}{c}\text { Medicine ball throw (LBM), vertical countermovement jump } \\
\text { (CMJV) and horizontal countermovement jump (CMJH). } \\
\text { Running speed: } \\
\text { 20-m maximum speed test }\end{array}$ \\
\hline & & & CG & $\begin{array}{l}\text { PE standardized curriculum: gymnastics skills, } \\
\text { team sports, dance, adventure sports, etc. }\end{array}$ & & & $\begin{array}{l}\text { VO2max: } \\
\text { 20-m round-trip test. }\end{array}$ \\
\hline
\end{tabular}


Table 1. Cont.

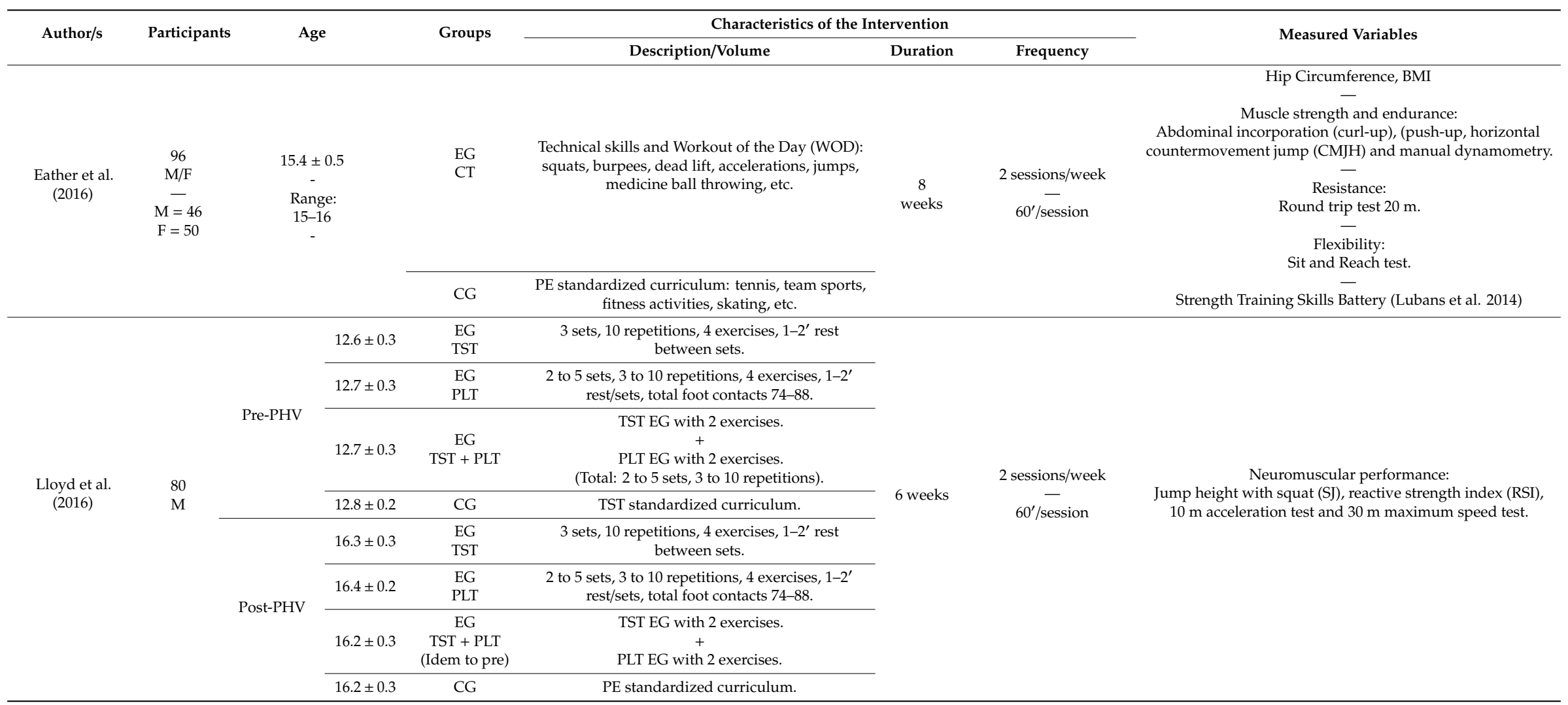


Table 1. Cont.

\begin{tabular}{|c|c|c|c|c|c|c|c|c|}
\hline \multirow{2}{*}{ Author/s } & \multirow{2}{*}{ Participants } & \multirow{2}{*}{\multicolumn{2}{|c|}{ Age }} & \multirow{2}{*}{ Groups } & \multicolumn{3}{|c|}{ Characteristics of the Intervention } & \multirow{2}{*}{ Measured Variables } \\
\hline & & & & & Description/Volume & Duration & Frequency & \\
\hline \multirow{8}{*}{$\begin{array}{l}\text { Radnor et al. } \\
\qquad(2017)\end{array}$} & \multirow{8}{*}{$\begin{array}{l}80 \\
\mathrm{M}\end{array}$} & \multirow{4}{*}{ Pre-PHV } & $12.6 \pm 0.3$ & $\begin{array}{l}\text { EG } \\
\text { RT }\end{array}$ & $\begin{array}{c}3 \text { sets, } 10 \text { repetitions, } 4 \text { exercises, } 1-2^{\prime} \text { rest } \\
\text { between sets. Increased load each week by } 5 \%\end{array}$ & \multirow{8}{*}{6 weeks } & \multirow{8}{*}{$\begin{array}{c}2 \text { sessions/week } \\
- \\
60^{\prime} / \text { session }\end{array}$} & \multirow{8}{*}{$\begin{array}{l}\text { Neuromuscular performance: } \\
\text { Jump height with squat (SJ), reactive strength index (RSI), } \\
10 \mathrm{~m} \text { acceleration test and } 30 \mathrm{~m} \text { maximum speed test. }\end{array}$} \\
\hline & & & $12.7 \pm 0.2$ & $\begin{array}{l}\text { EG } \\
\text { PLT }\end{array}$ & $\begin{array}{l}2 \text { to } 5 \text { sets, } 3 \text { to } 10 \text { repetitions, } 4 \text { exercises, } 1-2^{\prime} \text { rest } \\
\text { between sets. }\end{array}$ & & & \\
\hline & & & $12.7 \pm 0.3$ & $\begin{array}{c}\text { EG } \\
\mathrm{RT}+\mathrm{PLT}\end{array}$ & $\begin{array}{c}\text { TST EG with } 2 \text { exercises. } \\
+ \\
\text { PLT EG with } 2 \text { exercises. } \\
\text { (Total: } 2 \text { to } 5 \text { sets, } 3 \text { to } 10 \text { repetitions). }\end{array}$ & & & \\
\hline & & & $12.8 \pm 0.2$ & CG & PE standardized curriculum. & & & \\
\hline & & \multirow{4}{*}{ Post-PHV } & $16.3 \pm 0.3$ & $\begin{array}{l}\text { EG } \\
\text { RT }\end{array}$ & $\begin{array}{l}3 \text { sets, } 10 \text { repetitions, } 4 \text { exercises, } 1-2^{\prime} \text { rest } \\
\text { between sets. }\end{array}$ & & & \\
\hline & & & $16.4 \pm 0.2$ & $\begin{array}{l}\text { EG } \\
\text { PLT }\end{array}$ & $\begin{array}{l}2 \text { to } 5 \text { sets, } 3 \text { to } 10 \text { repetitions, } 4 \text { exercises, } 1-2^{\prime} \text { rest } \\
\text { between sets. }\end{array}$ & & & \\
\hline & & & $16.2 \pm 0.3$ & $\begin{array}{c}\text { EG } \\
\text { RT + PLT } \\
\text { (Idem to pre) }\end{array}$ & $\begin{array}{c}\text { TST EG with } 2 \text { exercises. } \\
+ \\
\text { PLT EG with } 2 \text { exercises. }\end{array}$ & & & \\
\hline & & & $16.2 \pm 0.3$ & CG & PE standardized curriculum. & & & \\
\hline \multirow[t]{2}{*}{$\begin{array}{l}\text { Guerra et al. } \\
\quad(2019)\end{array}$} & \multirow{2}{*}{$\begin{array}{c}24 \\
\mathrm{M} / \mathrm{F} \\
- \\
\mathrm{M}=14 \\
\mathrm{~F}=10\end{array}$} & \multirow{2}{*}{\multicolumn{2}{|c|}{$\begin{array}{c}15.7 \pm 0.84 \\
- \\
\text { Range: } \\
15-16\end{array}$}} & $\begin{array}{l}\text { EG } \\
\text { CAT }\end{array}$ & $\begin{array}{c}3 \text { sets/circuit laps: } \\
6 \text { exercises, } 30^{\prime \prime} \text { of execution and } 50^{\prime \prime} \text { of rest } \\
\text { between each circuit lap } \\
+ \\
\text { PE standardized curriculum. }\end{array}$ & \multirow[t]{2}{*}{8 weeks } & \multirow{2}{*}{$\begin{array}{c}2 \text { sessions/week } \\
- \\
60^{\prime} / \text { session } \\
\left(15^{\prime} \mathrm{CAT}\right. \\
+ \\
\left.45^{\prime} \mathrm{TST}\right)\end{array}$} & \multirow[t]{2}{*}{$\begin{array}{l}\text { Strength, endurance and muscle power: } \\
\text { Abdominal incorporation (curl-up), push-up, medicine ball } \\
\text { throwing } 3 \mathrm{~kg} \text { and horizontal jump. }\end{array}$} \\
\hline & & & & CG & $\begin{array}{c}\text { Stretching } \\
+ \\
\text { PE standardized curriculum. }\end{array}$ & & & \\
\hline
\end{tabular}

Note. $\mathrm{M}=$ Male, $\mathrm{F}=$ Female, BMI = Body Mass Index, PHV = Peak Height Velocity, PE = Physical Education, EG = Experimental Group, CG = Control Group, MST = Manual Strength Training, CRT $=$ Cardiorespiratory Resistance Training, FWST $=$ Free-Weight Strength Training, ETST $=$ Elastic-Tube Strength Training, BST $=$ Ballistic Strength Training, PT $=$ Power Training, $\mathrm{CT}=$ Crossfit Training, TST $=$ Traditional Strength Training, RT $=$ Resistance Training, PLT $=$ Plyometric Training, CAT $=$ Calisthenics Training 


\section{Results}

In the research conducted by Dorgo et al. [26], statistically significant differences were observed between the experimental group and the control group from a pre-post-test in the push-up test $(p<0.003)$ and curl-up test $(p<0.0001)$. Similar results were reported by Guerra et al. [29], with the experimental group obtaining better results in the post-test than the control group in both the push-up test $(p=0.001)$ and the curl-up $(p=0.019)$.

Regarding the results obtained by Lubans et al. [31] in the 1RM test, significant improvements in upper- $(p<0.01)$ and lower- body strength $(p<0.05)$ in both experimental groups (free weights and elastic tubes) when comparing with the control group were observed. However, these improvements in the upper body were greater with free weights, with an increase of $24 \%(d=1.2)$ versus $12 \%(d=0.6)$ in the group that trained with elastics. When considering the gender, girls achieved more significant improvements in the lower body $(p<0.05)$ with free weights $(32 \%$ increase, $\mathrm{d}=1.6$,$) compared to$ elastics $(19 \%$ increase, $d=1.1)$ and the control group $(d=0.5)$.

Santos et al. [33] found a significant improvement in the medicine ball throwing with pre-post-test $(p=0.00)$ when evaluating the strength of the upper body. Related to this, Eather et al. [27] found no significant improvement in the manual dynamometry.

On the other hand, Granacher et al. [28] observed a 17\% increase in maximum isometric strength in the experimental group at post-test $(p=0.007)$ after 8 weeks of plyometric training, being also higher compared to the control group. The $8 \%$ increase achieved by the experimental group in the countermovement vertical jump height from pre- to post-test was also significant $(p<0.001)$. However, in the case of Rate of Force Development (RFD), they found no differences between groups.

Similar results were obtained by Santos et al. (33) and Eather et al. [27] when evaluating the strength of the lower body through horizontal jump, finding significant improvements when comparing the experimental group and the control group ( $p=0.00$ for the first study and $p=0.02$ for the second one).

Lloyd et al. [30] and Radnor et al. [32] showed improvements in one or several aspects of muscle performance from the experimental groups, observing significant differences in squat-jump height from pre- to post-test $(p<0.01)$ in the group that did traditional strength training and the group that did combined strength-power training. However, regarding the reactive strength index, the most relevant improvements $(p<0.01)$ were found with power training and strength-power training.

Finally, Granacher et al. [28] included a short-term eight-week ballistic strength training program integrated in physical education lessons. This study included a post-test detraining phase in the protocol, finding positive results pre-post testing in the maximum isometric force and CMJ height (17\% improvement; $p=0.001)$, maintaining this improvement after detraining ( $9 \%$ improvement; $p=0.04$ ). Moreover, the results obtained by Santos et al. [33] after a 12-week detraining phase did not change significantly in the training group, finding no differences (losses) in the tests of medicine ball throwing, vertical jump, and horizontal jump when comparing the pre-test and the detraining phase.

\section{Discussion}

The results revealed that secondary school students who follow a strength training program during physical education classes achieve improvements in their muscle capacity compared to students who follow the normal curriculum of the Physical Education subject.

\subsection{Muscle Power Training and Muscle Strength}

At present, one of the most researched types of muscle strength training is related to performing training at high velocity and low loads, known as plyometric or power training [34]. Some of the research studies reviewed in this article have included power training for six-eight weeks, with substantial improvements observed in the 1RM test [31] and in the reactive strength index [30] in the group that performed the power training compared to the experimental group that trained strength in the traditional way (moderate loads and velocity). These findings are in line with those obtained by 
Faigenbaum et al. [35], who found significant improvements after applying a six-week plyometric training program in muscle capacity performing horizontal jump tests and medicine ball throwing, as well as in cardiovascular performance measured using a 20-m shuttle test.

\subsection{Traditional StrengthTtraining and Muscle Strength}

It has commonly been considered that children and young people should strength train with low loads; however, recent literature has shown that improvements in muscle fitness parameters in young people can also come from the use of moderate and high loads and movement velocity [36,37].

Several of the studies included in this review have observed significant improvements from preto post-test in 1RM test [31] or squat jumping [30,32] after applying a traditional strength training program, performing 8 to 12 repetitions per exercise, with intensities close to muscle failure. In these cases, an experimental group that power trained was also included in the study, observing in some cases greater improvements with this type of training [30,32], and in other cases, very similar results between groups [31].

Along the same lines, Assunção et al. [38] sought to compare the effects of different training loads (low and high) on young people, observing no differences between the two experimental groups. Similar results were found by Harries et al. [39] when comparing two different training loads.

Remarkably, chronological age is a weak indicator of maturational status [37]. In this way, a marked variation in biological age among children of the same chronological age group could be found in some of the studies included in the present systematic review $[26,27,29,31]$. However, other studies took into consideration the maturation status to allocate the sample $[30,32]$ or analyze if there were significant differences between groups [28,33]. Therefore, the analysis of biological age could affect the results of the studies since strength gains, structural and architectural changes are largely driven by hormonal concentrations [37].

Furthermore, future studies should report and follow the position statement and training guidelines for conducting training in order to optimize results. Lloyd et al. [37] published a position statement on youth resistance training where they recommended for adolescents without previous resistance training experience: low volume (1-2 sets, rest $1 \mathrm{~min})$ and low-moderate training intensities $(\leq 60 \% 1 \mathrm{RM})$ for a range of exercises and movement patterns. Likewise, the intensity of the training should be increased when the technique is safe: $2-4$ sets (rest $2-3 \mathrm{~min}$ ) of 6-12 repetitions, low-moderate intensity $(\leq 80 \% 1 \mathrm{RM})$.

\subsection{Concurrent Strength-Resistance Training and Muscle Strength}

Another training method gaining relevance in young people is concurrent strength-resistance training with possible benefits at muscle level [40]. Two articles in this review [26,33] found significant post-test improvements in push-up, jumping ability, curl-up and medicine ball throwing, although these improvements were not substantial compared to the group that trained strength in an isolated manner.

Similar results were obtained by Alves et al. [41] and Marta et al. [42], who, after applying a concurrent strength-resistance program, observed that it was no more effective than traditional strength training in the improvement of the medicine balls throwing or horizontal jumping.

However, as Alves et al. [41] and Gäbler et al. [43] pointed out, concurrent strength-resistance training does achieve more significant improvements in $\mathrm{VO}_{2}$ max compared to isolated strength training. In addition, strength training, i.e., circuit training, may improve cardiorespiratory fitness [44]. Therefore, more review studies analyzing the effects of strength training on cardiorespiratory fitness in this educational context and interventions are needed.

\subsection{Concurrent Strength-Power Training and Muscle-Strength}

Working on different motor manifestations within a single session, seeking to improve neuromuscular and cardiorespiratory adaptations, have been widely used methodologies in sports research [45]. 
Thus, Lloyd et al. [30] and Radnor et al. [32], included in this review, observed significant improvements in muscle strength in the post-test group that performed combined strength and power training in the same session, where the total training load (movement velocity, number of sets, repetitions, and so on) was different from the group that trained strength or power using an isolated strategy.

When comparing experimental groups with each other (combined strength-power, strength, or power), it was observed that combined S-P training always showed better improvements compared to the isolated training, regardless of the variable used for measurement of the age of the participants.

Similarly, Faigenbaum et al. [46] obtained very positive results in the push-up and horizontal jump test after an eight-week combined training program for the seven-eight-year-old group, including strength, power, and balance exercises in the same session.

\subsection{Type of Material Used and Muscle Strength}

Finding out the most effective training to significantly improve different aspects linked to muscle strength in children and adolescents [47] has been a subject of intense research for years. On this basis, the use of different kind of materials seems to be one of the most relevant decisions to be made in the design of the interventions, and it may influence the different adaptations to be generated [37].

In this regard, in recent years there has been a growing interest in the use of the body weight as a system for strength development [48]. Two of the papers included in this review [26,29] found positive post-test results in push-up and curl-up tests when performing exercises with the body weight or the partner's bodyweight.

Similarly, other studies have shown the positive effects on strength and power of calisthenics exercises in both children [49] and adolescents [50].

Rubber bands are another material widely recommended by the specialized literature to be used by pediatric populations for strength training [51]. In this review, this material was used by one of the experimental groups included in the work of Lubans et al. [31], achieving significant improvements in muscle strength with respect to the control group (performing the standardized Physical Education classes) but not with respect to the group that trained with free weights. Likewise, other experimental studies have shown improvements in the muscular capacity of the youngest after following a strength training program with elastic bands [52] and free weights [53].

\section{Practical Implications}

The strategies implemented in the studies reviewed could be a starting point for designing interventions in the context of Physical Education, in order to improve muscle strength in adolescents. In general, based on the results obtained and considering the latest international positioning on youth strength training [37], the basic recommendations for these interventions are:

- A minimum duration of six to eight weeks onwards, two days a week, to achieve a minimum neuromuscular adaptation, although it is recommended to maintain the program throughout several months or the entire academic year. It would be advisable to use pedagogical strategies that allow the integration of strength work in all sessions. For instance, incorporating a small strength training for the first $15 \mathrm{~min}$ of the lesson, followed by the regular curriculum of the subject for the remaining time, and thus, following the recommendations by Guerra et al. [29].

- Taking into account the students' background, their fitness level, and the duration of the Didactic Unit, it may be more interesting to implement a program of strength training including medium loads and velocity, especially in the first lessons, to create an optimum technical base that will later permit the correct execution of explosive exercises [54].

- A progressive load increase throughout the program, varying the external load as well as the training variables, in approximate ranges of $2-4$ sets, $8-14$ repetitions and $20-180 \mathrm{~s}$. of rest. 
- It is important to take into account the principle of progression and the availability of the material. It is recommended to progress from materials that require less motor control such as elastics, to materials that are more motor challenging such as dumbbells or medicine balls [37]. The use of the circuit training would be a good option to the didactic control of the group [51].

- Considering the academic load of Physical Education per week (usually ranged from 1.5 to $3 \mathrm{~h}$ ), it seems interesting to propose didactic units integrating sessions where two or more motor manifestations are simultaneously developed [45]. In this case, considering the studies reviewed, we recommend the use of concurrent strength-resistance training and combined training of power and traditional strength, in order to optimize muscular and cardio-respiratory adaptations.

\section{Conclusions}

This systematic review reveals positive results, highlighting the effectiveness of implementing intervention programs in the context of Secondary Education with the purpose of improving one or more of the physical abilities associated with muscle strength.

The inclusion of power exercises, traditional strength, concurrent strength-resistance and/or strength-power in Physical Education classes improves the muscle performance capacity of adolescents in jumping, throwing, acceleration, maximum repetition, and muscle endurance tests. In addition, different materials, such as elastic bands, free weights, body weight or medicine balls, have shown significant improvements in muscle strength. Although in some cases some strategies have resulted as more effective than others, all have achieved to significantly increase muscle capacity from pre- to post-test compared to the control group.

\section{Study Limitations and Foresight}

It is essential to highlight the heterogeneity between the different training methodologies used in each of the studies reviewed, especially concerning the type of material, the arrangement of the training variables during the session (repetitions $\mathrm{x}$ series), as well as in the duration of the programs. Therefore, it is complicated to establish precise recommendations about which strength training could be most effective to be incorporated in regular Secondary Physical Education sessions.

This diversification of methodologies indicates the importance of developing future research where different training methods may be compared with a similar workload.

Likewise, it would be interesting to carry out future scientific works studying the effects on muscular performance of brief strength training strategies (10-15 $\mathrm{min}$ ) at the beginning, during, or at the end of the Physical Education classes in Secondary School (continuing with the regular contents for the remaining class time). At the primary school level, there is evidence that this system is an optimal strategy to improve muscle strength, without eliminating other mandatory content [45]. Despite the benefits of using different resources to work the strength, more experimental studies comparing the effects of different materials are necessary.

Author Contributions: Conceptualization, C.G.-B., J.Á.R.-A., and D.J.R.-C.; methodology, C.G.-B., J.Á.R.-A., and D.J.R.-C.; software and formal analysis, C.G.-B., J.Á.R.-A., and DJRC; investigation, C.G.-B., J.Á.R.-A., and D.J.R.-C.; writing—original draft preparation, C.G.-B., J.Á.R.-A., L.M.M.-A., and D.J.R.-C.; writing—review and editing, C.G.-B., J.Á.R.-A., L.M.M.-A., and D.J.R.-C. All authors have read and agreed to the published version of the manuscript.

Funding: This research received no external funding.

Conflicts of Interest: The authors declare no conflict of interest. 


\section{References}

1. Román-Viñas, B.; Zazo, F.; Martínez-Martínez, J.; Aznar-Laín, S.; Serra-Majem, L. Results from Spain's 2018 report card on physical activity for children and youth. J. Phys. Act. Health 2018, 15, 411-412. [CrossRef]

2. World Health Organization. Global Recommendations on Physical Activity for Health. 2010. Available online: https://apps.who.int/iris/handle/10665/44399 (accessed on 14 February 2019).

3. Mielgo-Ayuso, J.; Aparicio-Ugarriza, R.; Castillo, A.; Ruiz, E.; Ávila, J.M.; Aranceta-Bartrina, J.; Gil, A.; Anta, R.M.O.; Serra-Majem, L.; Varela-Moreiras, G.; et al. Sedentary behavior among Spanish children and adolescents: Findings from the ANIBES study. BMC Public Health 2017, 17, 94. [CrossRef]

4. Chooi, Y.C.; Ding, C.; Magkos, F. The epidemiology of obesity. Metabolism 2019, 92, 6-10. [CrossRef]

5. World Health Organization. Commission Report to End Childhood Obesity. 2016. Available online: https://www.who.int/end-childhood-obesity/publications/echo-report/es/ (accessed on 19 February 2019).

6. Ortega, F.B.; Ruiz, J.R.; Castillo, M.J.; Sjöström, M. Physical fitness in childhood and adolescence: A powerful marker of health. Int. J. Obes. 2007, 32, 1-11. [CrossRef]

7. Ortega, F.B.; Ruiz, J.R.; Castillo, M.J.; Moreno, L.A.; González-Gross, M.; Wärnberg, J.; Gutiérrez, A. The AVENA group Low Level of Physical Fitness in Spanish Adolescents Relevance for Future Cardiovascular Health (AVENA Study). Rev. Española Cardiol. 2005, 58, 898-909. [CrossRef]

8. Galancho-Reina, I.; Sánchez-Oliver, A.J.; González-Matarín, P.J.; Butragueño, J.; Bandera-Merchan, B.; Suárez-Carmona, W.; Isidro-Donate, F.; Tinahones, F.J.; Macias-Gonzalez, M. The role of muscle tissue and resistance training in cardiometabolic health. Int. J. Sports Sci. Med. 2019, 3, 1-12.

9. Granacher, U.; Lesinski, M.; Büsch, D.; Muehlbauer, T.; Prieske, O.; Puta, C.; Gollhofer, A.; Behm, D.G. Effects of Resistance Training in Youth Athletes on Muscular Fitness and Athletic Performance: A Conceptual Model for Long-Term Athlete Development. Front. Physiol. 2016, 7, 164. [CrossRef]

10. Smith, J.J.; Eather, N.; Morgan, P.J.; Plotnikoff, R.; Faigenbaum, A.D.; Lubans, D.R. The Health Benefits of Muscular Fitness for Children and Adolescents: A Systematic Review and Meta-Analysis. Sports Med. 2014, 44, 1209-1223. [CrossRef]

11. Padilla-Moledo, C.; Ruiz, J.R.; Ortega, F.B.; Mora, J.; Piñero, J.C. Associations of Muscular Fitness With Psychological Positive Health, Health Complaints, and Health Risk Behaviors in Spanish Children and Adolescents. J. Strength Cond. Res. 2012, 26, 167-173. [CrossRef]

12. García-Hermoso, A.; Ramírez-Campillo, R.; Izquierdo, M. Is Muscular Fitness Associated with Future Health Benefits in Children and Adolescents? A Systematic Review and Meta-Analysis of Longitudinal Studies. Sports Med. 2019, 49, 1079-1094. [CrossRef]

13. Moliner-Urdiales, D.; Ruiz, J.R.; Ortega, F.B.; Jiménez-Pavón, D.; Vicente-Rodriguez, G.; Rey-López, J.; Martínez-Gómez, D.; Casajús, J.; Mesana, M.; Marcos, A.; et al. Secular trends in health-related physical fitness in Spanish adolescents: The AVENA and HELENA Studies. J. Sci. Med. Sport 2010, 13, 584-588. [CrossRef]

14. Faigenbaum, A.D.; Macdonald, J.P. Dynapenia: It's not just for grown-ups anymore. Acta Paediatr. 2017, 106, 696-697. [CrossRef]

15. Zwolski, C.; Quatman-Yates, C.; Paterno, M.V. Resistance Training in Youth: Laying the Foundation for Injury Prevention and Physical Literacy. Sports Health A Multidiscip. Approach 2017, 9, 436-443. [CrossRef]

16. Pozuelo-Carrascosa, D.P.; Cavero-Redondo, I.; Herráiz-Adillo, Á.; Díez-Fernández, A.; López, M.S.; Martinez-Vizcaino, V. School-Based Exercise Programs and Cardiometabolic Risk Factors: A Meta-analysis. Pediatrics 2018, 142, e20181033. [CrossRef]

17. Lloyd, R.S.; Oliver, J.L. The Youth Physical Development Model. Strength Cond. J. 2012, 34, 61-72. [CrossRef]

18. Chen, S.; Kim, Y.; Gao, Z. The contributing role of physical education in youth's daily physical activity and sedentary behavior. BMC Public Health 2014, 14, 110. [CrossRef]

19. Comisión Europea/EACEA/Eurydice. La Educación Física Y el Deporte en Los Centros Escolares de Europa; Informe de Eurydice; Oficina de Publicaciones de la Unión Europea: Luxemburgo, 2013. [CrossRef]

20. Minatto, G.; Filho, V.C.B.; Berria, J.; Petroski, E.L. School-Based Interventions to Improve Cardiorespiratory Fitness in Adolescents: Systematic Review with Meta-analysis. Sports Med. 2016, 46, 1273-1292. [CrossRef] 
21. Lai, S.K.; Costigan, S.A.; Morgan, P.J.; Lubans, D.R.; Stodden, D.; Salmon, J.; Barnett, L.M. Do school-based interventions focusing on physical activity, fitness, or fundamental movement skill competency produce a sustained impact in these outcomes in children and adolescents? A Systematic Review of Follow-Up Studies. Sports Med. 2013, 44, 67-79. [CrossRef]

22. Watson, A.; Timperio, A.; Brown, H.; Best, K.; Hesketh, K. Effect of classroom-based physical activity interventions on academic and physical activity outcomes: A systematic review and meta-analysis. Int. J. Behav. Nutr. Phys. Act. 2017, 14, 114. [CrossRef]

23. Moher, D.; Shamseer, L.; Clarke, M.; Ghersi, D.; Liberati, A.; Petticrew, M.; Shekelle, P.G.; Stewart, L. Preferred reporting items for systematic review and meta-analysis protocols (PRISMA-P) 2015 statement. Syst. Rev. 2015, 4, 1. [CrossRef]

24. Centro Cochrane Iberoamericano. Manual Cochrane de Revisiones Sistemáticas de Intervenciones; versión 5.1.0; Centro Cochrane Iberoamericano: Barcelona, Spain, 2012. Available online: http://www.cochrane.es/?q=es/ node/269 (accessed on 10 April 2019).

25. Higgins, J.P.T.; Altman, U.G.; Gøtzsche, P.C.; Jüni, P.; Moher, D.; Oxman, A.D.; Savović, J.; Schulz, K.F.; Weeks, L.; Sterne, J.A.C. The Cochrane Collaboration's tool for assessing risk of bias in randomised trials. BMJ 2011, 343, d5928. [CrossRef]

26. Dorgo, S.; King, G.A.; Candelaria, N.G.; Bader, J.O.; Brickey, G.D.; Adams, C.E. Effects of manual resistance training on fitness in adolescents. J. Strength Cond. Res. 2009, 23, 2287-2294. [CrossRef]

27. Eather, N.; Morgan, P.J.; Lubans, D.R. Improving health-related fitness in adolescents: The CrossFit Teens ${ }^{\mathrm{TM}}$ randomised controlled trial. J. Sports Sci. 2016, 34, 209-223. [CrossRef]

28. Granacher, U.; Muehlbauer, T.; Doerflinger, B.; Strohmeier, R.; Gollhofer, A. Promoting strength and balance in adolescents during physical education: Effects of a short-term resistance training. J. Strength Cond. Res. 2011, 25, 940-949. [CrossRef]

29. Guerra, L.A.; Dos Santos, L.R.; Pereira, P.E.; Lauria, V.T.; De Lima, C.; Evangelista, A.L.; Rica, R.L.; Bocalini, D.S.; Messias, C.B.; Teixeira, C.V.L. A low-cost and time-efficient calisthenics strength training program improves fitness performance of children. J. Phys. Educ. Sport 2019, 19, 58-62.

30. Lloyd, R.S.; Radnor, J.M.; De Ste Croix, M.B.; Cronin, J.B.; Oliver, J.L. Changes in sprint and jump performances after traditional, plyometric, and combined resistance training in male youth pre-and post-peak height velocity. J. Strength Cond. Res. 2016, 30, 1239-1247. [CrossRef]

31. Lubans, D.R.; Sheaman, C.; Callister, R. Exercise adherence and intervention effects of two school-based resistance training programs for adolescents. Prev. Med. 2010, 50, 56-62. [CrossRef]

32. Radnor, J.M.; Lloyd, R.S.; Oliver, J.L. Individual response to different forms of resistance training in school-aged boys. J. Strength Cond. Res. 2017, 31, 787-797. [CrossRef]

33. Santos, A.P.; Marinho, D.A.; Costa, A.M.; Izquierdo, M.; Marques, M.C. The effects of concurrent resistance and endurance training follow a detraining period in elementary school students. J. Strength Cond. Res. 2012, 26, 1708-1716. [CrossRef]

34. Singla, D.; Hussain, M.E.; Moiz, J.A. Effect of upper body plyometric training on physical performance in healthy individuals: A systematic review. Phys. Ther. Sport 2018, 29, 51-60. [CrossRef]

35. Faigenbaum, A.D.; McFarland, J.E.; Keiper, F.B.; Tevlin, W.; Ratamess, N.A.; Kang, J.; Hoffman, J.R. Effects of a Short-Term Plyometric and Resistance Training Program on Fitness Performance in Boys Age 12 to 15 Years. J. Sports Sci. Med. 2007, 6, 519-525.

36. Faigenbaum, A.D.; Milliken, L.; Moulton, L.; Westcott, W.L. Early Muscular Fitness Adaptations in Children in Response to Two Different Resistance Training Regimens. Pediatr. Exerc. Sci. 2005, 17, 237-248. [CrossRef]

37. Lloyd, R.S.; Faigenbaum, A.D.; Stone, M.H.; Oliver, J.L.; Jeffreys, I.; A Moody, J.; Brewer, C.; Pierce, K.C.; McCambridge, T.M.; Howard, R.; et al. Position statement on youth resistance training: The 2014 International Consensus. Br. J. Sports Med. 2013, 48, 498-505. [CrossRef]

38. Assunção, A.R.; Bottaro, M.; Ferreira-Junior, J.B.; Izquierdo, M.; Cadore, E.L.; Gentil, P. The Chronic Effects of Low- and High-Intensity Resistance Training on Muscular Fitness in Adolescents. PLoS ONE 2016, 11, e0160650. [CrossRef]

39. Harries, S.K.; Lubans, D.R.; Callister, R. Comparison of resistance training progression models on maximal strength in sub-elite adolescent rugby union players. J. Sci. Med. Sport 2016, 19, 163-169. [CrossRef]

40. Coffey, V.G.; Hawley, J.A. Concurrent exercise training: Do opposites distract? J. Physiol. 2016, 595, $2883-2896$. [CrossRef] 
41. Alves, A.R.; Marta, C.C.; Neiva, H.P.; Izquierdo, M.; Marques, M.C. Concurrent Training in Prepubescent Children. J. Strength Cond. Res. 2016, 30, 2019-2032. [CrossRef]

42. Marta, C.; A Marinho, D.; Barbosa, T.M.; Izquierdo, M.; Marques, M.C. Effects of Concurrent Training on Explosive Strength and VO2max in Prepubescent Children. Int. J. Sports Med. 2013, 34, 888-896. [CrossRef]

43. Gäbler, M.; Prieske, O.; Hortobágyi, T.; Granacher, U. The Effects of Concurrent Strength and Endurance Training on Physical Fitness and Athletic Performance in Youth: A Systematic Review and Meta-Analysis. Front. Physiol. 2018, 9, 9. [CrossRef]

44. Muñoz-Martínez, F.A.; Rubio-Arias, J.Á.; Ramos-Campo, D.J.; Alcaraz, P.E. Effectiveness of Resistance Circuit-Based Training for Maximum Oxygen Uptake and Upper-Body One-Repetition Maximum Improvements: A Systematic Review and Meta-Analysis. Sports Med. 2017, 47, 2553-2568. [CrossRef]

45. Faigenbaum, A.D.; Myer, G.D. Pediatric Resistance Training. Curr. Sports Med. Rep. 2010, 9, 161-168. [CrossRef]

46. Faigenbaum, A.D.; Farrell, A.; Fabiano, M.; Radler, T.; Naclerio, F.; Ratamess, N.A.; Kang, J.; Myer, G.D. Effects of integrative neuromuscular training on fitness performance in children. Pediatr. Exerc. Sci. 2011, 23, 573-584. [CrossRef]

47. Schranz, N.; Tomkinson, G.; Olds, T.S. What is the Effect of Resistance Training on the Strength, Body Composition and Psychosocial Status of Overweight and Obese Children and Adolescents? A Systematic Review and Meta-Analysis. Sports Med. 2013, 43, 893-907. [CrossRef]

48. Del Río Alijas, R.; Díaz Torre, A.H. Calistenia: Volviendo a los orígenes. EmásF 2015, 33, 87-96.

49. Santos, D.; de Oliveira, T.E.; Pereira, C.A.; Evangelista, A.L.; Sales, D.; Bocalini, R.L. Does a calisthenics-based exercise program applied in school improve morphofunctional parameters in youth? J. Exerc. Physiol. Online 2015, 18, 52-62.

50. Krishnan, K.; Arumugam, C. The effect of callisthenic and dumbbell exercise on muscular strength endurance and flexibility of rural school boys. Int. J. Innov. Res. Dev. 2013, 2, 367-375.

51. Pena, G.; Heredia, J.; Lloret, C.; Martin, M.; Da Silva-Grigoletto, M. Iniciación al entrenamiento de fuerza en edades tempranas: Revisión. Rev. Andal. Med. Deport. 2016, 9, 41-49. [CrossRef]

52. Annesi, J.J.; Westcott, W.L.; Faigenbaum, A.D.; Unruh, J.L. Effects of a 12-Week Physical Activity Protocol Delivered by YMCA After-School Counselors (Youth Fit for Life) on Fitness and Self-Efficacy Changes in 5-12-Year-Old Boys and Girls. Res. Q. Exerc. Sport 2005, 76, 468-476. [CrossRef]

53. Sadres, E.; Eliakim, A.; Constantini, N.; Lidor, R.; Falk, B. The Effect of Long-Term Resistance Training on Anthropometric Measures, Muscle Strength, and Self Concept in Pre-Pubertal Boys. Pediatr. Exerc. Sci. 2001, 13, 357-372. [CrossRef]

54. Lloyd, R.S.; Meyers, R.W.; Oliver, J.L. The Natural Development and Trainability of Plyometric Ability During Childhood. Strength Cond. J. 2011, 33, 23-32. [CrossRef] 